4




Coordenação editorial: José Morais Arnaud, César Neves e Andrea Martins Design gráfico: Flatland Design

AAP - ISBN: 978-972-9451-89-8

CITCEM - ISBN: 978-989-8970-25-1

Associação dos Arqueólogos Portugueses e CITCEM

Lisboa, 2020

O conteúdo dos artigos é da inteira responsabilidade dos autores. Sendo assim a Associação dos Arqueólogos Portugueses declina qualquer responsabilidade por eventuais equívocos ou questões de ordem ética e legal.

Desenho de capa:

Planta do castro de Monte Mozinho (Museu Municipal de Penafiel).

\section{$\hat{\wedge} \mathrm{P}$}

DOS ARQUEÓLOGOS PORTUGUESES

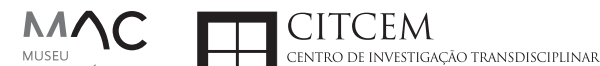
MUSEU
ARQUELLÓGICO
DO CARMO
U.PORTO

FLUP FACULDADE DE LETRAS
UNIVERSIDADE DO PORTO

Apoio

EC para a Ciência 


\section{Índice}

15 Prefácio

José Morais Arnaud

\section{Historiografia e Teoria}

17 Território, comunidade, memória e emoção: a contribuição da história da arqueologia (algumas primeiras e breves reflexões)

Ana Cristina Martins

25 Como descolonizar a arqueologia portuguesa?

Rui Gomes Coelho

41 Arqueologia e Modernidade: uma revisitação pessoal e breve de alguns aspetos da obra homónima de Julian Thomas de 2004

Vítor Oliveira Jorge

57 Dados para a História das Mulheres na Arqueologia portuguesa, dos finais do século XIX aos inícios do século XX: números, nomes e tabelas

Filipa Dimas / Mariana Diniz

73 Retractos da arqueologia portuguesa na imprensa: (in)visibilidades no feminino

Catarina Costeira / Elsa Luís

85 Arqueologia e Arqueólogos no Norte de Portugal Jacinta Bugalhão

101 Vieira Guimarães (1864-1939) e a arqueologia em Tomar: uma abordagem sobre o território e as gentes

João Amendoeira Peixoto / Ana Cristina Martins

115 Os memoráveis? A arqueologia algarvia na imprensa nacional e regional na presente centúria (2001-2019): características, visões do(s) passado(s) e a arqueologia

enquanto marca

Frederico Agosto / João Silva

129 A Evolução da Arqueologia Urbana e a Valorização Patrimonial no Barlavento Algarvio: Os casos de Portimão e Silves

Artur Mateus / Diogo Varandas / Rafael Boavida

\section{Gestão, Valorização e Salvaguarda do Património}

145 O Caderno Reivindicativo e as condições de trabalho em Arqueologia Miguel Rocha / Liliana Matias Carvalho / Regis Barbosa / Mauro Correia / Sara Simões / Jacinta Bugalhão / Sara Brito / Liliana Veríssimo Carvalho / Richard Peace / Pedro Peça / Cézer Santos

155 Os Estudos de Impacte Patrimonial como elemento para uma estratégia sustentável de minimização de impactes no âmbito de reconversões agrícolas Tiago do Pereiro

165 Salvaguarda de Património arqueológico em operações florestais: gestão e sensibilização Filipa Bragança / Gertrudes Zambujo / Sandra Lourenço / Belém Paiva / Carlos Banha / Frederico Tatá Regala / Helena Moura / Jacinta Bugalhão / João Marques / José Correia / Pedro Faria / Samuel Melro

179 Os valores do Património: uma investigação sobre os Sítios Pré-históricos de Arte Rupestre do Vale do Rio Côa e de Siega Verde José Paulo Francisco 
189 Conjugando recursos arqueológicos e naturais para potenciar as visitas ao Geoparque Litoral de Viana do Castelo (Noroeste de Portugal)

Hugo A. Sampaio / Ana M.S. Bettencourt / Susana Marinho / Ricardo Carvalhido

203 Áreas de Potencial Arqueológico na Região do Médio Tejo: Modelo Espacial Preditivo Rita Ferreira Anastácio / Ana Filipa Martins / Luiz Oosterbeek

223 Património Arqueológico e Gestão Territorial: O contributo da Arqueologia para a revisão do PDM de Avis

Ana Cristina Ribeiro

237 A coleção arqueológica do extinto Museu Municipal do Porto - Origens, Percursos e Estudos

Sónia Couto

251 Valpaços - uma nova carta arqueológica

Pedro Pereira / Maria de Fátima Casares Machado

263 Arqueologia na Cidade de Peniche

Adriano Constantino / Luís Rendeiro

273 Arqueologia Urbana: a cidade de Lagos como caso de Estudo Cátia Neto

285 Estratégias de promoção do património cultural subaquático nos Açores. O caso da ilha do Faial

José Luís Neto / José Bettencourt / Luís Borges / Pedro Parreira

297 Carta Arqueológica da Cidade Velha: Uma primeira abordagem

Jaylson Monteiro / Nireide Tavares / Sara da Veiga / Claudino Ramos / Edson Brito /

Carlos Carvalho / Francisco Moreira / Adalberto Tavares

311 Antropologia Virtual: novas metodologias para a análise morfológica e funcional Ricardo Miguel Godinho / Célia Gonçalves

\section{Didáctica da Arqueologia}

327 Como os projetos de Arqueologia podem contribuir para uma comunidade culturalmente mais consciente Alexandra Figueiredo / Claúdio Monteiro / Adolfo Silveira / Ricardo Lopes

337 Educação Patrimonial - Um cidadão esclarecido é um cidadão ativo! Ana Paula Almeida

351 A aproximação da Arqueologia à sala de aula: um caso de estudo no $3^{\circ}$ ciclo do Ensino Básico Luís Serrão Gil

363 Arqueologia 3.o - Pensar e comunicar a Arqueologia para um futuro sustentável Mónica Rolo

377 “Conversa de Arqueólogos" - Divulgar a Arqueologia em tempos de Pandemia Diogo Teixeira Dias

389 Escola Profissional de Arqueologia: desafios e oportunidades Susana Nunes / Dulcineia Pinto / Júlia Silva / Ana Mascarenhas

399 Os Museus de Arqueologia e os Jovens: a oferta educativa para o público adolescente Beatriz Correia Barata / Leonor Medeiros

411 O museu universitário como mediador entre a ciência e a sociedade: o exemplo da secção de arqueologia no Museu de História Natural e da Ciência da Universidade do Porto (MHNC-UP)

Rita Gaspar 
421 Museu de Lanifícios: Real Fábrica de Panos. Atividades no âmbito da Arqueologia Beatriz Correia Barata / Rita Salvado

427 Arqueologia Pública e o caso da localidade da Mata (Torres Novas) Cláudia Manso / Ana Rita Ferreira / Cristiana Ferreira / Vanessa Cardoso Antunes

431 Do sítio arqueológico ao museu: um percurso (também) didático Lídia Fernandes

447 Estão todos convidados para a Festa! E para dançar também... O projecto do Serviço Educativo do Museu Arqueológico do Carmo na $5^{\underline{a}}$ Edição da Festa da Arqueologia Rita Pires dos Santos

459 O “Clã de Carenque”, um projeto didático de arqueologia Eduardo Gonzalez Rocha

469 Mediação cultural: peixe que puxa carroça nas Ruínas Romanas de Troia Inês Vaz Pinto / Ana Patrícia Magalhães / Patrícia Brum / Filipa Santos

481 Didática Arqueológica, experiências do Projeto Mértola Vila Museu Maria de Fátima Palma / Clara Rodrigues / Susana Gómez / Lígia Rafael

\section{Arte Rupestre}

497 Os inventários de arte rupestre em Portugal Mila Simões de Abreu

513 O projeto FIRST-ART - conservação, documentação e gestão das primeiras manifestações de arte rupestre no Sudoeste da Península Ibérica: as grutas do Escoural e Maltravieso Sara Garcês / Hipólito Collado / José Julio García Arranz / Luiz Oosterbeek / António Carlos Silva / Pierluigi Rosina / Hugo Gomes / Anabela Borralheiro Pereira / George Nash / Esmeralda Gomes / Nelson Almeida / Carlos Carpetudo

523 Trabalhos de documentação de arte paleolítica realizados no âmbito do projeto PalæoCôa André Tomás Santos / António Fernando Barbosa / Luís Luís / Marcelo Silvestre / Thierry Aubry

537 Imagens fantasmagóricas, silhuetas elusivas: as figuras humanas na arte do Paleolítico Superior da região do Côa Mário Reis

$55^{1}$ Os motivos zoomórficos representados nas placas de tear de Vila Nova de São Pedro (Azambuja, Portugal) Andrea Martins / César Neves / José M. Arnaud / Mariana Diniz

571 Arte Rupestre do Monte de Góios (Lanhelas, Caminha). Síntese dos resultados dos trabalhos efectuados em 2007-2009 Mário Varela Gomes

599 Gravuras rupestres de barquiformes no Monte de S. Romão, Guimarães, Noroeste de Portugal Daniela Cardoso

613 Círculos segmentados gravados na Bacia do Rio Lima (Noroeste de Portugal): contributos para o seu estudo Diogo Marinho / Ana M.S. Bettencourt / Hugo Aluai Sampaio

631 Equídeos gravados no curso inferior do Rio Mouro, Monção (NW Portugal). Análise preliminar Coutinho, L.M. / Bettencourt, A.M.S / Sampaio, Hugo A.S

645 Paletas na Arte Rupestre do Noroeste de Portugal. Inventário preliminar Bruna Sousa Afonso / Ana M. S. Bettencourt / Hugo A. Sampaio 


\section{Pré-História}

661 O projeto Miño/Minho: balanço de quatro anos de trabalhos arqueológicos Sérgio Monteiro-Rodrigues / João Pedro Cunha-Ribeiro / Eduardo Méndez-Quintas / Carlos Ferreira / Pedro Xavier / José Meireles / Alberto Gomes / Manuel Santonja / Alfredo Pérez-González

677 A ocupação paleolítica da margem esquerda do Baixo Minho: a indústria lítica do sítio de Pedreiras 2 (Monção, Portugal) e a sua integração no contexto regional Carlos Ferreira / João Pedro Cunha-Ribeiro / Sérgio Monteiro-Rodrigues / Eduardo Méndez-Quintas / Pedro Xavier / José Meireles / Alberto Gomes / Manuel Santonja / Alfredo Pérez-González

693 O sítio acheulense do Plistocénico médio da Gruta da Aroeira Joan Daura / Montserrat Sanz / Filipa Rodrigues / Pedro Souto / João Zilhão

703 As sociedades neandertais no Barlavento algarvio: modelos preditivos com recurso aos SIG

Daniela Maio

715 A utilização de quartzo durante o Paleolítico Superior no território dos vales dos rios Vouga e Côa

Cristina Gameiro / Thierry Aubry / Bárbara Costa / Sérgio Gomes / Luís Luís / Carmen Manzano / André Tomás Santos

733 Uma perspetiva diacrónica da ocupação do concheiro do Cabeço da Amoreira (Muge, Portugal) a partir da tecnologia lítica Joana Belmiro / João Cascalheira / Célia Gonçalves

745 Novos dados sobre a Pré-história Antiga no concelho de Palmela. A intervenção arqueológica no sítio do Poceirão I

Michelle Teixeira Santos

757 Problemas em torno de Datas Absolutas Pré-Históricas no Norte do Alentejo Jorge de Oliveira

771 Povoamento pré-histórico nas áreas montanhosas do NO de Portugal: o Abrigo 1 de Vale de Cerdeira Pedro Xavier / José Meireles / Carlos Alves

783 Apreciação do povoamento do Neolítico Inicial na Baixa Bacia do Douro. A Lavra I (Serra da Aboboreira) como caso de estudo Maria de Jesus Sanches

797 O Processo de Neolitização na Plataforma do Mondego: os dados do Sector C do Outeiro dos Castelos de Beijós (Carregal do Sal)

João Carlos de Senna-Martinez / José Manuel Quintã Ventura / Andreia Carvalho / Cíntia Maurício

823 Novos trabalhos na Lapa da Bugalheira (Almonda, Torres Novas) Filipa Rodrigues / Pedro Souto / Artur Ferreira / Alexandre Varanda / Luís Gomes / Helena Gomes / João Zilhão

837 A pedra polida e afeiçoada do sítio do Neolítico médio da Moita do Ourives (Benavente, Portugal)

César Neves

857 Casal do Outeiro (Encarnação, Mafra): novos contributos para o conhecimento do povoamento do Neolítico final na Península de Lisboa.

Cátia Delicado / Carlos Maneira e Costa / Marta Miranda / Ana Catarina Sousa

873 Stresse infantil, morbilidade e mortalidade no sítio arqueológico do Neolítico Final/ Calcolítico ( $4^{\circ}$ e $3^{\circ}$ milénio a.C.) do Monte do Carrascal 2 (Ferreira do Alentejo, Beja) Liliana Matias de Carvalho / Sofia N. Wasterlain 
885 Come together: O Conjunto Megalítico das Motas (Monção, Viana do Castelo) e as expressões Campaniformes do Alto Minho Ana Catarina Basílio / Rui Ramos

899 Trabalhos arqueológicos no sítio Calcolítico da Pedreira do Poio Carla Magalhães / João Muralha / Mário Reis / António Batarda Fernandes

913 O sítio arqueológico de Castanheiro do Vento. Da arquitectura do sítio à arquitectura de um território João Muralha Cardoso

925 Estudo zooarqueológico das faunas do Calcolítico final de Vila Nova de São Pedro (Azambuja, Portugal): Campanhas de 2017 e 2018 Cleia Detry / Ana Catarina Francisco / Mariana Diniz / Andrea Martins / César Neves / José Morais Arnaud

943 As faunas depositadas no Museu Arqueológico do Carmo provenientes de Vila Nova de São Pedro (Azambuja): as campanhas de 1937 a 1967 Ana Catarina Francisco / Cleia Detry / César Neves / Andrea Martins / Mariana Diniz / José Morais Arnaud

959 Análise funcional de material lítico em sílex do castro de Vila Nova de S. Pedro (Azambuja, Portugal): uma primeira abordagem Rafael Lima

971 O recinto da Folha do Ouro 1 (Serpa) no contexto dos recintos de fossos calcolíticos alentejanos

António Carlos Valera / Tiago do Pereiro / Pedro Valério / António M. Monge Soares

\section{Proto-História}

987 Produção de sal marinho na Idade do Bronze do noroeste Português. Alguns dados para uma reflexão

Ana M. S. Bettencourt / Sara Luz / Nuno Oliveira / Pedro P. Simões / Maria Isabel C. Alves / Emílio Abad-Vidal

1001 A estátua-menir do Pedrão ou de São Bartolomeu do Mar (Esposende, noroeste de Portugal) no contexto arqueológico da fachada costeira de entre os rios Neiva e Cávado Ana M. S. Bettencourt / Manuel Santos-Estévez / Pedro Pimenta Simões / Luís Gonçalves

1015 O Castro do Muro (Vandoma/Baltar, Paredes) - notas para uma biografia de ocupação da Idade do Bronze à Idade Média

Maria Antónia D. Silva / Ana M. S. Bettencourt / António Manuel S. P. Silva / Natália Félix

1031 Do Bronze Final à Idade Média - continuidades e hiatos na ocupação de Povoados em Oliveira de Azeméis João Tiago Tavares / Adriaan de Man

1041 As faunas do final da Idade do Bronze no Sul de Portugal: leituras desde o Outeiro do Circo (Beja)

Nelson J. Almeida / Íris Dias / Cleia Detry / Eduardo Porfírio / Miguel Serra

1055 A Espada do Monte das Oliveiras (Serpa) - uma arma do Bronze Pleno do Sudoeste Rui M. G. Monge Soares / Pedro Valério / Mariana Nabais / António M. Monge Soares

1065 São Julião da Branca (Albergaria-a-Velha) - Investigação e valorização de um povoado do Bronze Final

António Manuel S. P. Silva / Paulo A. P. Lemos / Sara Almeida e Silva / Edite Martins de Sá

1083 Do castro de S. João ao Mosteiro de Santa Clara: notícia de uma intervenção arqueológica, em Vila do Conde Rui Pinheiro 
1095 O castro de Ovil (Espinho), um quarto de século de investigação - resultados e questões em aberto

Jorge Fernando Salvador / António Manuel S. P. Silva

1111 O Castro de Salreu (Estarreja), um povoado proto-histórico no litoral do Entre Douro e Vouga

Sara Almeida e Silva / António Manuel S. P. Silva / Paulo A. P. Lemos / Edite Martins de Sá

1127 Castro de Nossa Senhora das Necessidades (Sernancelhe): uma primeira análise artefactual Telma Susana O. Ribeiro

${ }_{1141}$ A cividade de Bagunte. O estado atual da investigação Pedro Brochado de Almeida

1153 Zoomorfos na cerâmica da Idade do Ferro no NW Peninsular: inventário, cronologias e significado Nuno Oliveira / Cristina Seoane

1163 Vasos gregos em Portugal: diferentes maneiras de contar a história do intercâmbio cultural na Idade do Ferro

Daniela Ferreira

1175 Os exotica da necrópole da Idade do Ferro do Olival do Senhor dos Mártires (Alcácer do Sal) no seu contexto regional

Francisco B. Gomes

\section{Antiguidade Clássica e Tardia}

1191 O uso de madeira como combustível no sítio da Quinta de Crestelos (Baixo Sabor): da Idade do Ferro à Romanização Filipe Vaz / João Tereso / Sérgio Simões Pereira / José Sastre / Javier Larrazabal Galarza / Susana Cosme / José António Pereira / Israel Espi

1207 Cultivos de Época Romana no Baixo Sabor: continuidade em tempos de mudança? João Pedro Tereso / Sérgio Simões Pereira / Filipe Santos / Luís Seabra / Filipe Vaz

1221 A casa romana na Hispânia: aplicação dos modelos itálicos nas províncias ibéricas Fernanda Magalhães / Diego Machado / Manuela Martins

1235 As pinturas murais romanas da Rua General Sousa Machado, n. ${ }^{5}$ 1, Chaves José Carvalho

1243 Trás do Castelo (Vale de Mir, Pegarinhos, Alijó) - Uma exploração agrícola romana do Douro

Tony Silvino / Pedro Pereira

1255 A sequência de ocupação no quadrante sudeste de Bracara Augusta: as transformações de uma unidade doméstica Lara Fernandes / Manuela Martins

1263 Os Mosaicos com decoração geométrica e geométrico-vegetalista dos sítios arqueológicos da área do Conuentus Bracaraugustanus. Novas abordagens quanto à conservação, restauro, decoração e datação Maria de Fátima Abraços / Licínia Wrench

1277 “Casa Romana” do Castro de São Domingos (Cristelos, Lousada): Escavação, Estudo e Musealização Paulo André de P. Lemos

1291 A arqueobotânica no Castro de Guifões (Matosinhos, Noroeste de Portugal): O primeiro estudo carpológico

Luís Seabra / Andreia Arezes / Catarina Magalhães / José Varela / João Pedro Tereso 
1305 Um Horreum Augustano na Foz do Douro (Monte do Castelo de Gaia, Vila Nova de Gaia) Rui Ramos

1311 Ponderais romanos na Lusitânia: padrões, formas, materiais e contextos de utilização Diego Barrios Rodríguez

1323 Um almofariz centro-itálico na foz do Mondego

Marco Penajoia

1335 Estruturas romanas de Carnide - Lisboa Luísa Batalha / Mário Monteiro / Guilherme Cardoso

1347 O contexto funerário do sector da "necrópole NO" da Rua das Portas de S. Antão (Lisboa): o espaço, os artefactos, os indivíduos e a sua interconectividade na interpretação do passado Sílvia Loja, José Carlos Quaresma, Nelson Cabaço, Marina Lourenço, Sílvia Casimiro, Rodrigo Banha da Silva, Francisca Alves-Cardoso

${ }_{1361}$ Povoamento em época Romana na Amadora - resultados de um projeto pluridisciplinar Gisela Encarnação / Vanessa Dias

1371 A Arquitectura Residencial em Mirobriga (Santiago do Cacém): contributo a partir de um estudo de caso Filipe Sousa / Catarina Felício

${ }_{1385}$ O fim do ciclo. Saneamento e gestão de resíduos nos edifícios termais de Mirobriga (Santiago do Cacém)

Catarina Felício / Filipe Sousa

1399 Balsa, Topografia e Urbanismo de uma Cidade Portuária Vítor Silva Dias / João Pedro Bernardes / Celso Candeias / Cristina Tété Garcia

1413 No Largo das Mouras Velhas em Faro (2017): novas evidências da necrópole norte de Ossonoba e da sua ocupação medieval Ricardo Costeira da Silva / Paulo Botelho / Fernando Santos / Liliana Nunes

1429 Instrumentos de pesca recuperados numa fábrica de salga em Ossonoba (Faro) Inês Rasteiro / Ricardo Costeira da Silva / Paulo Botelho

1439 A Necrópole Romana do Eirô, Duas Igrejas (Penafiel): intervenção arqueológica de 2016 Laura Sousa / Teresa Soeiro

1457 Ritual, descarte ou afetividade? A presença de Canis lupus familiaris na Necrópole Noroeste de Olisipo (Lisboa)

Beatriz Calapez Santos / Sofia Simões Pereira / Rodrigo Banha da Silva / Sílvia Casimiro / Cleia Detry / Francisca Alves Cardoso

1467 Dinâmicas económicas em Bracara na Antiguidade Tardia Diego Machado / Manuela Martins / Fernanda Magalhães / Natália Botica

1479 Cerâmicas e Vidros da Antiguidade Tardia do Edifício sob a Igreja do Bom Jesus (Vila Nova de Gaia) Joaquim Filipe Ramos

1493 Novos contributos para a topografia histórica de Mértola no período romano e na Antiguidade Tardia Virgílio Lopes

\section{8. Época Medieval}

1511 Cerâmicas islâmicas no Garb setentrional "português": algumas evidências e incógnitas Constança dos Santos / Helena Catarino / Susana Gómez / Maria José Gonçalves / Isabel Inácio / Gonçalo Lopes / Jacinta Bugalhão / Sandra Cavaco / Jaquelina Covaneiro / Isabel Cristina Fernandes / Ana Sofia Gomes 
1525 Contributo para o conhecimento da cosmética islâmica, em Silves, durante a Idade Média Rosa Varela Gomes

1537 Yábura e o seu território - uma análise histórico-arqueológica de Évora entre os séculos VIII-XII José Rui Santos

1547 A encosta sul do Castelo de Palmela - resultados preliminares da escavação arqueológica Luís Filipe Pereira / Michelle Teixeira Santos

1559 A igreja de São Lourenço (Mouraria, Lisboa): um conjunto de silos e de cerâmica medieval islâmica

Andreia Filipa Moreira Rodrigues

1571 O registo material de movimentações populacionais no Médio Tejo, durante os séculos XII-XIII. Dois casos de "sunken featured buildings", nos concelhos de Cartaxo e Torres Novas Marco Liberato / Helena Santos / Nuno Santos

1585 O nordeste transmontano nos alvores da Idade média. Notas para reflexão Ana Maria da Costa Oliveira

1601 Sepulturas escavadas na rocha do Norte de Portugal e do Vale do Douro: primeiros resultados do Projecto SER-NPVD

Mário Jorge Barroca / César Guedes / Andreia Arezes / Ana Maria Oliveira

1619 "Portucalem Castrum Novum" entre o Mediterrâneo e o Atlântico: o estudo dos materiais cerâmicos alto-medievais do arqueossítio da rua de D. Hugo, nํ. 5 (Porto) João Luís Veloso

1627 A Alta Idade Média na fronteira de Lafões: notas preliminares sobre a Arqueologia no Concelho de Vouzela

Manuel Luís Real / Catarina Tente

1641 Um conjunto cerâmico medieval fora de portas: um breve testemunho aveirense Susana Temudo

${ }_{1651}$ Os Lóios do Porto: uma perspetiva integrada no panorama funerário da Baixa Idade Média à Época Moderna em meios urbanos em Portugal

Ana Lema Seabra

1659 O Caminho Português Interior de Santiago como eixo viário na Idade Média Pedro Azevedo

1665 Morfologia Urbana: Um exercício em torno do Castelo de Ourém André Donas-Botto / Jaqueline Pereira

1677 Intervenção arqueológica na Rua Marquês de Pombal/Largo do Espírito Santo (Bucelas, Loures)

Florbela Estêvão / Nathalie Antunes-Ferreira / Dário Ramos Neves / Inês Lisboa

1691 O Cemitério Medieval do Poço do Borratém e a espacialidade funerária na cidade de Lisboa Inês Belém / Vanessa Filipe / Vasco Noronha Vieira / Sónia Ferro / Rodrigo Banha da Silva

1705 Um Espaço Funerário Conventual do séc. XV em Lisboa: o caso do Convento de São Domingos da Cidade Sérgio Pedroso / Sílvia Casimiro / Rodrigo Banha da Silva / Francisca Alves Cardoso

\section{9. Época Moderna e Contemporânea}

1721 Arqueologia Moderna em Portugal: algumas reflexões críticas em torno da quantificação de conjuntos cerâmicos e suas inferências históricas e antropológicas Rodrigo Banha da Silva / André Bargão / Sara da Cruz Ferreira

1733 Faianças de dois contextos entre os finais do século XVI e XVIII do Palácio dos Condes de Penafiel, Lisboa

Martim Lopes / Tomás Mesquita 
1747 Um perfil de consumo do século XVIII na foz do Tejo: O caso do Mercado da Ribeira, Lisboa Sara da Cruz Ferreira / Rodrigo Banha da Silva / André Bargão

1761 Os Cachimbos dos Séculos XVII e XVIII do Palácio Mesquitela e Convento dos Inglesinhos (Lisboa)

Inês Simão / Marina Pinto / João Pimenta / Sara da Cruz Ferreira / André Bargão / Rodrigo Banha da Silva

1775 "Tomar os fumos da erua que chamão em Portugal erua sancta». Estudo de Cachimbos provenientes da Rua do Terreiro do Trigo, Lisboa

Miguel Martins de Sousa / José Pedro Henriques / Vanessa Galiza Filipe

1787 Cachimbos de Barro Caulínitico da Sé da Cidade Velha (República de Cabo Verde)

Rodrigo Banha da Silva / João Pimenta / Clementino Amaro

1801 Algumas considerações sobre espólio não cerâmico recuperado no Largo de Jesus (Lisboa) Carlos Boavida

1815 Adereços de vidro, dos séculos XVI-XVIII, procedentes do antigo Convento de Santana de Lisboa (anéis, braceletes e contas)

Joana Gonçalves / Rosa Varela Gomes / Mário Varela Gomes

1837 Da ostentação, luxo e poder à simplicidade do uso quotidiano: arqueologia e simbologia de joias e adornos da Idade Moderna Portuguesa Jéssica Iglésias

1849 Os amuletos em Portugal - dos objetos às superstições: o coral vermelho Alexandra Vieira

1865 Cerâmicas de Vila Franca de Xira nos séculos XV e XVI Eva Pires

1879 «Não passa por teu o que me pertence». Marcas de individualização associadas a faianças do Convento de Nossa Senhora de Aracoeli, Alcácer do Sal Catarina Parreira / Íris Fragoso / Miguel Martins de Sousa

1891 Cerâmica de Leiria: alguns focos de produção

Jaqueline Pereira / André Donas-Botto

1901 Os Fornos na Rua da Biquinha, em Óbidos Hugo Silva / Filipe Oliveira

1909 A casa de Pêro Fernandes, contador dos contos de D. Manuel I: o sítio arqueológico da Silha do Alferes, Seixal (século XVI) Mariana Nunes Ferreira

1921 O Alto da Vigia (Sintra) e a vigilância e defesa da costa Alexandre Gonçalves / Sandra Santos

1937 O contexto da torre sineira da Igreja de Santa Maria de Loures Paulo Calaveira / Martim Lopes

1949 A Necrópole do Hospital Militar do Castelo de São Jorge e as práticas funerárias na Lisboa de Época Moderna Susana Henriques / Liliana Matias de Carvalho / Ana Amarante / Sofia N. Wasterlain

1963 SAND - Sarilhos Grandes Entre dois Mundos: o adro da Igreja e a Paleobiologia dos ossos humanos recuperados

Paula Alves Pereira / Roger Lee Jesus / Bruno M. Magalhães

1975 Expansão urbana da vila de Cascais no século XVII e XVIII: a intervenção arqueológica na Rua da Vitória no 15 a 17

Tiago Pereira / Vanessa Filipe

1987 Novos dados para o conhecimento do Urbanismo de Faro em época Moderna Ana Rosa 
1995 Um exemplo de Arqueologia Urbana em Alcoutim: o Antigo Edifício dos CTT Marco Fernandes / Marta Dias / Alexandra Gradim / Virgílio Lopes / Susana Gómez Martínez

2007 Palácio dos Ferrazes (Rua das Flores/Rua da Vitória, Porto): a cocheira de Domingos Oliveira Maia

Francisco Raimundo

2021 As muitas vidas de um edifício urbano: História, Arqueologia e Antropologia no antigo Recreatório Paroquial de Penafiel Helena Bernardo / Jorge Sampaio / Marta Borges

2035 O convento de Nossa Senhora da Esperança de Ponta Delgada: o contributo da arqueologia para o conhecimento de um monumento identitário João Gonçalves Araújo / N’Zinga Oliveira

2047 Arqueologia na ilha do Corvo... em busca da capela de Nossa Senhora do Rosário Tânia Manuel Casimiro / José Luís Neto / Luís Borges / Pedro Parreira

2059 Perdidos à vista da Costa. Trabalhos arqueológicos subaquáticos na Barra do Tejo Jorge Freire / José Bettencourt / Augusto Salgado

2071 Arqueologia marítima em Cabo Verde: enquadramento e primeiros resultados do projecto CONCHA

José Bettencourt / Adilson Dias / Carlos Lima / Christelle Chouzenoux / Cristóvão Fonseca / Dúnia Pereira / Gonçalo Lopes / Inês Coelho / Jaylson Monteiro / José Lima / Maria Eugénia Alves / Patrícia Carvalho / Tiago Silva

2085 Trabalhos arqueológicos na Cidade Velha (Ribeira Grande de Santiago, Cabo Verde): reflexões sobre um projecto de investigação e divulgação patrimonial André Teixeira / Jaylson Monteiro / Mariana Mateus / Nireide Tavares / Cristovão Fonseca / Gonçalo C. Lopes / Joana Bento Torres / Dúnia Pereira / André Bargão / Aurélie Mayer / Bruno Zélie / Carlos Lima / Christelle Chouzenoux / Inês Henriques / Inês Pinto Coelho / José Lima / Patrícia Carvalho / Tiago Silva

2103 A antiga fortificação de Quelba / Khor Kalba (E.A.U.). Resultados de quatro campanhas de escavações, problemáticas e perspectivas futuras Rui Carita / Rosa Varela Gomes / Mário Varela Gomes / Kamyar Kamyad

2123 Colónias para homens novos: arqueologia da colonização agrária fascista no noroeste ibérico Xurxo Ayán Vila / José Mạ . Señorán Martín 


\title{
CASTRO DE NOSSA SENHORA DAS NECESSIDADES (SERNANCELHE): UMA PRIMEIRA ANÁLISE ARTEFACTUAL
}

Telma Susana O. Ribeiro ${ }^{1}$

\begin{abstract}
RESUMO
O Castro de Nossa Senhora das Necessidades é, até à data, o único sítio arqueológico do concelho de Sernancelhe (distrito de Viseu) a ser discutido na bibliografia arqueológica. Referido como um castro do Bronze Final, o sítio tem vindo a ser destruído e conta apenas com recolhas superficiais que nunca foram estudadas de forma a dar a conhecer todas as suas ocupações. Assim, esta primeira análise, feita através de materiais cerâmicos, líticos e metálicos que resultam de prospecções ao cabeço, vem revelar outras cronologias para este sítio, procurando assim contribuir para a sua valorização e a compreensão da cultura material e povoamento da Beira Alta em alguns dos seus períodos pré-históricos e medievais.
\end{abstract}

Palavras-chave: Beira Alta, Pré-História Recente, Idade do Ferro, Medieval, Análise artefactual.

\begin{abstract}
The Nossa Senhora das Necessidades settlement is to date the only archaeological site in the county of Sernancelhe (Viseu district) to be discussed in the archaeological literature. Referred to as a settlement from the Late Bronze Age, the site has been continually destroyed and has only superficial findings that have never been studied so that we know all of its occupations. This first study, made through ceramic, lithic and metallic artefacts that result from prospections at the hill, aims to reveal the other chronologies of this site, seeking to contribute to the comprehension of the material culture and settlement network of the Beira Alta region in some of its prehistoric and medieval times.
\end{abstract}

Keywords: Beira Alta, Late Prehistory, Iron Age, Medieval, Artifactual study.

\section{O SÍTIO: LOCALIZAÇÃO E ENQUADRAMENTO}

O Castro de Nossa Senhora das Necessidades (CSN) localiza-se no topo de uma elevação conhecida como "Alto da Borralheira", na freguesia de Vila da Ponte, concelho de Sernancelhe, distrito de Viseu, com as coordenadas $40^{\circ} 54^{\prime} 46.4$ " $\mathrm{N}$ de Latitude e $7^{\circ} 31^{\prime} 25.9$ " W de Longitude na folha 159 da Carta Militar a 1/25000 (Figura 1).

A elevação, com altitude de cerca de $754 \mathrm{~m}$, está encaixada entre os vales da ribeira de Arados a Oeste e do rio Távora a Norte e Este, onde a paisagem foi alterada pela construção de uma barragem na década de 1960, formando agora uma albufeira (Figura 2). O sítio tem um grande domínio visual das serras da Lapa, Leomil e Estrela, dos seus vales e dos cas- telos de Sernancelhe e Caria. A região é constituída maioritariamente por granitos porfiróides de idade hercínia onde abundam os filões de quartzo branco. Estes solos ácidos são mais férteis nas margens do rio Távora que proporcionam a plantação de hortícolas, pomares, vinhas e soutos numa paisagem maioritariamente marcada por pinheiros, carvalhos, freixos, vimeiros e espécies arbustivas como as giestas e urzes. Ocupações antigas do sítio eram já apontadas pela lenda local da existência de habitações "mouriscas" que serviriam de vigia e comunicação aos castelos e cujas estruturas teriam sido reaproveitadas para a construção da primeira capela. O historiador Pinho Leal (1873, pp. 16o-161) refere o sítio como uma atalaia "construída pelos antigos lusitanos" e Vasco Moreira (1929, p. 253) acredita que a povoação de Vila da Ponte terá tido origem neste sítio. Por volta de 1400

1. UNIARQ; telmaribeiro@campus.ul.pt 
foi construída no topo deste monte uma pequena capela a St ${ }^{\mathrm{a}}$ Bárbara que foi em meados do séc. XVI ampliada para dedicação a Nossa Senhora das Necessidades, tendo-se construído ao longo do tempo todo um complexo religioso à sua volta que inclui outras capelas, a "casa do ermitão", altares exteriores, uma cerca, serviços de água canalizada, jardins, uma antena de comunicações e vários caminhos de acesso. Estas construções, suas consequentes obras de reparação e ainda a extracção de granito acabaram por destruir grande parte deste sítio arqueológico que contém também algumas grutas naturais que foram abrigo de romeiros e anacoretas.

\section{OS CONJUNTOS, SEUS CONTEXTOS DE RECOLHA E METODOLOGIA DE ESTUDO}

O presente estudo baseia-se em 3 conjuntos de materiais recolhidos à superfície no sítio, num total de 114 peças, das quais 98 são olaria, 14 são líticos e 2 são metais. O primeiro encontra-se sob a tutela da Uniarq e foi recolhido em 2001 em prospecções realizadas pela equipa do PEABMAM ${ }^{2}$. As recolhas foram na altura triadas e inventariadas tendo-se diferenciado os seus contextos de superfície designados por: abrigos, zona de convívio, subida, topo, vertente este e área geral. Procedemos a uma segunda triagem, resultando num conjunto de 59 peças classificáveis, das quais 9 são líticos, 2 são barro seco, 1 é escória, e os restantes são fragmentos cerâmicos. O segundo conjunto é o resultado das prospecções de 2005 realizadas pelo arqueológo António Costa do então Gabinete Técnico da Câmara Municipal de Sernancelhe no âmbito da realização da Carta Arqueológica de Sernancelhe, publicada em 2007. Este conjunto encontra-se nas instalações da mesma Câmara e apesar de já estar inventariado, não estava triado nem apresentava contextos, considerando-se também de uma área geral. Para evitar confusão, atribuímos novos números de inventário às peças, no seguimento da numeração do primeiro conjunto. Após a nossa triagem contamos com 27 fragmentos cerâmicos, 2 líticos e 1 escória, num total de 30 peças classificáveis. O terceiro conjunto foi recolhido pela signatária numa visita ao sítio na Primavera do presente ano. Recolheram-se e foram inventariados 25 fragmentos cerâmicos classificáveis e 3 líticos, todos

2. Programa de Estudo Arqueológico da Bacia do Médio e Alto Mondego provenientes da vertente Nordeste onde a abertura de um novo estradão deixou muito material à superfície e em iminente perigo de destruição.

Perante a constatação de pelo menos 3 períodos cronológicos no conjunto total de artefactos, procedeu-se ao seu estudo através da divisão das peças por grupos: as que remetem para o Calcolítico; as que remetem para o Bronze Final/Idade do Ferro; as medievais; as "indiferenciáveis", ou seja, aquelas sem período cronológico seguramente atribuível; e os líticos. Para cada um dos grupos foi criada uma matriz de dados, com a caracterização de todas as peças, que serve de base para a discussão de cada ocupação do sítio, procurando sempre paralelos próximos para poder compreendê-las no contexto da região e sua cultura material. No entanto, este processo esteve sempre truncado por diferenças metodológicas entre estudos e falta generalizada de investigações na região.

\section{UMA PRIMEIRA OCUPAÇÃO NO III ${ }^{\circ}$ MILÉNIO A.C.}

Até ao surgimento de novos dados, a primeira ocupação deste sítio deverá situar-se no período do Calcolítico. Tal é-nos comprovado por um total de 20 fragmentos cerâmicos decorados, dos quais 5 são bordos (Figura 3). É de referir que a maioria dos fragmentos apresentam um grande nível de erosão apesar de estarem pouco rolados. Ainda assim, verificamos que as pastas são todas compactas e xistosas, à excepção de duas únicas peças de textura granular, e a maioria com desengordurantes pequenos e pouco frequentes, compostos por quartzo, micas e feldspatos, apontando para uma produção local. As colorações das peças demonstram uma tendência por cozeduras oxidantes, embora a sua irregularidade resulte num número igual de cozeduras mistas. Verificam-se ainda casos de cozeduras com arrefecimentos opostos e duas únicas peças de cozedura totalmente redutora. Os acabamentos são preferencialmente por alisamento simples, mas 6 das peças apresentam polimento de pelo menos uma das faces, verificando-se ainda o espatulamento da face interior de uma delas. Confirma-se também a presença de aguadas ou engobes em 8 peças, com preferência para a face exterior. Estes fabricos vão, de modo geral, ao encontro do que já se conhece para a olaria calcolítica da região do Alto Mondego onde também predominam as pastas compactas, 
texturas xistosas, elementos não plásticos pequenos ou médios e relativamente frequentes, cozeduras oxidantes e acabamentos cuidados por alisamento ou polimento com recorrência a engobe (Valera, 1993; Valera, 2007).

Todos os bordos permitiram calcular os diâmetros, que caem entre os 11 e os $22 \mathrm{~cm}$. Apesar da grande fragmentação destes, podemos ainda assim perceber a sua morfologia, 3 dos quais remetem para formas fechadas, nomeadamente um vaso esférico (forma 5) e um vaso de colo troncocónico (forma 9). Os restantes aparentam pertencer a tigelas (forma 4), com a particularidade de uma delas remeter para a forma 4.6, de lábio exvertido (no 92). Tal remete às tabelas de formas calcolíticas construídas para os vários povoados da região da Beira Alta (Valera, 2007; Senna-Martinez, 1989) que são constituídas essencialmente por tigelas e formas fechadas de "fundo neo-calcolitíco" baseadas em esferas e elipses (Valera, 1993; Valera, 2007).

Relativamente às decorações, reinam os penteados ondulados, com alguns casos de penteados descontínuos (num exemplar com recurso a métopas polidas). No entanto, destaca-se um único exemplar com incisão pré-cozedura com uma faixa de reticulados em cruz sobre uma canelura ( $\mathrm{n}^{\circ} \mathrm{95}$ ). Enquanto os penteados são bem conhecidos pelo centro/norte do território actualmente português para as fases mais recentes do III- milénio, nomeadamente na Fraga da Pena, Quinta das Rosas (ambos em Fornos de Algodres), Murganho 1, Corujeira (ambos em Nelas), entre outros da região (Valera, 2007, pp. 370371), esta última decoração reticulada é mais rara, mas com paralelos, por exemplo, no sítio da Malhada (Fornos de Algodres) (Valera, 2007, p. 203).

Esta ocupação torna-se na primeira comprovada para o período calcolítico no concelho. Também não se conhecem necrópoles ou reutilizações da mesma cronologia nas imediações, algo que, no entanto, resultará apenas da falta de investigações. De facto, o que a área estudada do Alto Mondego (Valera, 2007) nos demonstra é que provavelmente existiria uma vasta rede de povoamento em torno do nosso sítio, marcada por povoados abertos, sazonais, juntos a cursos de água, em zonas mais aplanadas e sem domínio visual. Como paralelos próximos ao CSN surgem-nos a Fraga da Pena e, especialmente, o Castro de Santiago (Fornos de Algodres), povoados de altura com grande domínio visual e aproveitamento da geomorfologia do sítio para defesa natural, tendo este último sido fundado ainda na primeira metade do III ${ }^{\circ}$ milénio a.C. (Valera, 2007). No entanto, ao contrário do Castro de Santiago onde os penteados são raros, a abundância desta decoração no nosso sítio leva-nos a colocá-lo já em meados ou último quartel do IIIo milénio. Tanto a Fraga da Pena como o Castro de Santiago apresentam ainda estruturas defensivas, algo que poderá também ter existido no CSN. Conhecem-se ainda ocupações calcolíticas em abrigos, como é o caso do Buraco da Moura de S. Romão (Seia) (Valera, 1993) que, semelhante ao nosso sítio e seus respectivos abrigos, teve ocupação desde o Calcolítico, passando pelo Bronze Final, até ao período medieval. Apenas com prospecções não poderemos saber a estruturação de CSN neste período, nem dizer qual a sua extensão ou adiantar muito mais sobre a sua cultura material, mas os sítios escavados demonstram que os povoados seriam essencialmente áreas habitacionais de estruturas de cabana, muitas vezes aproveitando os afloramentos graníticos, construídas com ramagens revestidas a barro, com lareiras centrais e a presença de fossas (Valera, 2007). Além da cerâmica, costumam estar presentes pesos de tear, elementos de moagem e uma indústria lítica de resíduos de talhe e artefactos laminares em sílex (Valera, 2007).

\section{DA IDADE DO BRONZE À IDADE DO FERRO}

Como referido, este sítio é já identificado na bibliografia arqueológica como um castro do Bronze Final, isto devido ao aparecimento de uma ponta de lança em bronze. No entanto, estamos perante uma cronologia que apresenta várias problemáticas relativamente à sua transição para a Idade do Ferro nesta região. É apontado um "colapso" para as comunidades do Bronze Final da Beira Alta, verificando-se um repentino abandono da grande maioria dos povoados até finais do séc. VIII a.C., muitos só voltando a ser ocupados no período romano. No entanto, cremos que esta ideia de "hiato" resulta essencialmente de uma grande falha na investigação: uma maioria de sítios prospectados e não escavados e ainda o uso de diferentes conceitos e metodologias nos estudos. Existem sítios escavados, como o Castelo dos Mouros (Viseu), que nos demonstram uma clara continuidade para a Idade do Ferro, altura em que a sua ocupação se intensifica (Pedro, 1995, pp. 48-49; Almeida, 2005, p. 115). 
Também nos castros de Santa Luzia (Viseu) e Senhora da Guia de Baiões (S. Pedro do Sul) algumas estruturas e materiais recolhidos, nomeadamente cerâmicas estampilhadas, podem remeter para a Idade do Ferro (Vaz, 200o, p. 136). Muitos outros sítios só com recolhas superficiais apontam também para ocupações que se estendem a esse período (Pedro, 1995; Vaz, 200o). Assim, ainda que alguns sítios terão sido abandonados, outros terão sido reocupados durante uma $2^{\underline{a}}$ Idade do Ferro e, em alguns casos, poderemos mesmo verificar uma continuidade de ocupação que se poderá definir como um "período de transição" que alguns autores têm apoiado (Betterncourt, 2005; Silva, 2008; Ribeiro, 2017, p. 44). No fundo, não existem dados suficientes para poder definir nesta região uma $\mathbf{1}^{\mathbf{a}}$ Idade do Ferro que, até agora, parece ser uma extensão do Bronze Final, em termos de povoamento e cultura material, apenas com a introdução de pequenas novidades. Como aponta Senna-Martinez (2013, pp. 181-182), mesmo a $2^{\underline{a}}$ Idade do Ferro só é seguramente identificável com vestígios de uma "revolução urbana", em torno do séc. V a.C., ou até só com a romanização. Tudo isto serve para ilustrar como num sítio não escavado, como CSN, se torna muito complexo conseguir separar materiais do Bronze Final dos que remetem à Idade do Ferro. Assim, procedemos à divisão entre 3 subgrupos de materiais que identificámos como provenientes de entre estas balizas cronológicas: os que têm paralelos no Bronze Final; os que se conhecem da Idade do Ferro ou período de transição; e os que poderão facilmente pertencer a qualquer um dos períodos em causa.

Para o Bronze Final contamos com 2 carenas, 2 bojos decorados e uma base em omphalos (Figura 3), por serem fragmentos que seguem as características mais marcantes do "Mundo Baiões/Santa Luzia", grupo cultural que melhor define esse período na região. Assim, incluímos peças de pasta compacta, com textura xistosa e cozedura redutora (algumas mistas), com acabamentos muito polidos/brunidos sobre engobe interior e exterior. Quanto a morfologias, procurou-se que as peças remetessem para a tabela de Senna-Martinez (1989) para o Bronze Final da Beira Alta e, apesar da ausência de bordos neste subgrupo, foi possível corresponder os bojos a taças ou pequenos potes por se tratarem de cerâmicas de pequena espessura e bons acabamentos, com a típica decoração "tipo Baiões” de motivos triangulares. Quanto à base em omphalos ( $\mathrm{n}^{\circ} 52$ ), raras na Idade do Ferro, poderá remeter a taças de Forma 32 ou Forma 38, mas também a urnas de Forma 37, segundo os paralelos apontados na mesma tabela. Relativamente às carenas, o ângulo e acabamentos da $n^{\circ} 25$ aponta-nos para um possível prato de Forma 31. Já a carena $\mathrm{n}^{\circ} 77$, provavelmente da Forma 32.1, apesar de ser de cozedura mista onde sobressai a componente oxidante e de superfícies alisadas, apresenta reticulados por incisão pós-cozedura, com paralelos semelhantes em Canedotes (Vila Nova de Paiva) (Canha, 2002).

Como prováveis da Idade do Ferro incluímos 3 bordos a torno, 3 bordos manuais e 3 bojos decorados. Todos apresentam uma pasta compacta e com pouca frequência de desengordurantes, que apontam na sua maioria para produções regionais. Os fragmentos de mais evidente cronologia da $2^{\underline{a}}$ Idade do Ferro são os bojos decorados (Figura 4): as peças nำ 5 e 22 são decoradas com estampilhas, a primeira em círculos concêntricos e a segunda com triângulos concêntricos, caneluras e um padrão de pequenos quadrados, com paralelos muito próximos, por exemplo, no Morro da Sé de Viseu (Almeida, 2005). Já o fragmento $\mathrm{n}^{\mathrm{o}} 125$ é também estampilhado, mas com recurso a roleta, técnica também testemunhada na $2^{2}$ Idade do Ferro, nomeadamente em Aeminium (Almeida \& alii, 2011, p. 44). Quanto aos 3 bordos manuais (Figura 3), é essencialmente a sua forma que os coloca na Idade do Ferro ou, pelo menos, na fase de transição. As peças nํำ 102 e 103 são bordos espessos, com uma média de $23 \mathrm{~cm}$ de diâmetro e exvertidos, um com lábio horizontal e o outro oblíquo, ambos passíveis a serem cobertos por um testo. Estes tipos de bordos não são conhecidos de níveis anteriores à transição para a Idade do Ferro, mas estão bem representados nos médios/grandes potes de armazenagem da $2^{\underline{a}}$ Idade do Ferro, podendo as superfícies interiores polidas sobre engobe destes exemplares indicar a funcionalidade de armazenagem de líquidos. De facto, destaca-se ainda um testo ( $n$ o 61), de cozedura redutora e de frequentes e grandes desengordurantes, mas com um acabamento brunido sobre engobe na sua face superior. Os testos são conhecidos essencialmente a partir da Idade do Ferro e são a pasta e acabamento desta peça que nos levam a atribuir-lhe uma cronologia proto-histórica e não medieval. Já o bordo nํㅜㄴ, de $28 \mathrm{~cm}$ de diâmetro e espessura de quase $1 \mathrm{~cm}$, apresenta-nos paredes direitas, de forma troncocónica. O seu ângulo forma um bocal muito aberto e aparenta não desenhar um 
colo ou carena, pelo que nos sugere tratar-se de uma tigela (quase prato) que se aproxima da Forma 8B da tabela para o Castro de Tavarede (Figueira da Foz) (Neves, 2013, p. 36), onde ocorrem igualmente com acabamentos polidos, encontrando também paralelos em Sabugal Velho (Osório, 2009).

Relativamente aos 3 bordos a torno (Figura 3), dois deles apontam para influências exógenas, ou até mesmo importações. As peças no 89 e 127 são de cozedura redutora, com a típica coloração cinzenta esbranquiçada, com ambas as faces alisadas e sem engobes. Enquanto a primeira apresenta um bordo redondo e deverá corresponder a uma pequena taça, a segunda apresenta um raro bordo "cabeça de pato" com diâmetro de $14 \mathrm{~cm}$. Esta última aponta para contactos, directos ou indirectos, com a Meseta central já que encontramos paralelos para este tipo de bordo em ambientes de Cogotas II, mas também em sítios como o Morro da Sé de Viseu (Almeida, 2005, p.7980) e Sabugal Velho (Osório, 2009, p. 102), embora estejam na sua origem e nestes sítios referidos associados a potes de armazenagem. $\mathrm{O}$ terceiro bordo a torno ( $\mathrm{n}^{\circ} 70$ ), de $13 \mathrm{~cm}$ de diâmetro e apenas $0,5 \mathrm{~cm}$ de espessura, trata-se de um fabrico de tradição local, com cozedura muito redutora, superfícies polidas e engobe interno, muito na linha dos potes do Bronze Final. No entanto, é o facto de ser fabricado a torno e de ter as suas linhas de bordo e colo bem demarcadas que o coloca na Idade do Ferro, com inúmeros paralelos no Morro da Sé de Viseu (potinhos, Forma $2 \mathrm{C}$ ) (Almeida, 2005), Sabugal (Osório, 2009) e Castelo dos Mouros (Pedro, 1995), entre outros.

Resta-nos o grupo de fragmentos que pelo seu fabrico e acabamento apontam para uma cronologia de entre os finais da Idade do Bronze e Idade do Ferro, mas que carecem de características suficientes para poder especificar o seu período (Figura 4). Neste grupo contamos com 11 bordos, 2 bases, 1 asa de fita e 1 bojo com ressalto, todos com o mesmo problema: pastas e acabamentos cuidados e típicos da região para os períodos das Idades do Bronze e Ferro, mas uma fragmentação que nos impede de atribuir morfologias específicas. Os bordos remetem para formas abertas, de gargalo, e têm diâmetros que vão dos 9 aos $22 \mathrm{~cm}$ e espessuras que vão dos 0,4 aos $1,04 \mathrm{~cm}$, a maioria provavelmente de potes de armazenagem. Ainda assim, a maioria tem poucos desengordurantes visíveis e de pequeno calibre. As pastas são compactas, xistosas e a maioria de cozedura redutora. A grande maioria é também de acabamento polido, por vezes um brunido intenso, em ambas as faces, e em alguns casos sobre engobe. Três destes bordos apresentam decoração no lábio, um por digitação, outro por punção (n⿳o 101) e outro por incisão e ungulação (no 107 ), técnicas e motivos decorativos que são típicos ao longo dos dois períodos. Relativamente às bases, mais uma vez a sua pasta e acabamentos cuidados remetem para um fabrico típico das Idades do Bronze e Ferro, assim como a sua forma plana. No entanto, é pela mesma razão de manutenção de morfologias e fabricos de bases ao longo dos dois períodos que nos é impossível atribuí-las a um período específico. Nenhuma permite calcular diâmetro.

Como referido, a grande maioria dos povoados do Bronze Final/Idade do Ferro da Beira Alta nunca foram escavados, como acontece com CSN. Ainda assim, regista-se que a instalação da maioria dos povoados terá ocorrido entre os séculos XIV e XIII a.C., e verifica-se uma grande preferência por lugares de altura, em cabeços entre os 400 e $700 \mathrm{~m}$ de altitude (Senna-Martinez, 1989), o que faz do CSN um dos de maior altitude. Esta implantação prende-se com o grande domínio visual e condições naturais de defesa, de forma a controlar as redes de contactos e o território envolvente, neste caso do vale do Távora. Relaciona-se também com as riquezas naturais das zonas planálticas e montanhosas em minério, pastos e linhas de água, aspectos que ganham mais importância na Idade do Ferro (Almeida, 2005, p. 113). No geral são povoados de pequena dimensão que se complementariam com outros sítios ainda mais pequenos, "atalaias", em seu redor e em pontos estratégicos. O CSN poderia estar interrelacionado com o sítio do Castelo de Sernancelhe ${ }^{3}$, onde também se verifica uma ocupação do Bronze Final e Idade do Ferro, não sendo possível, no entanto, saber exactamente qual a relação entre os dois. Regista-se também que os povoados do Bronze Final seriam fundados de raiz, no entanto, a escavação do Outeiro do Castelo de Beijós (Carregal do Sal) (Senna-Martinez, 20ooa, p. 45) demonstrou que já existia uma ocupação desde os finais do Neolítico, vindo agora o CSN também refutar essa teoria. As habitações destes povoados seriam simples cabanas sub-circulares, construídas em materiais

3. Ainda sem publicação, o sítio foi escavado em sondagens no ano de 2019 com a signatária como interveniente, podendo assim testemunhar estas ocupações no sítio. 
perecíveis, por vezes com fundações em pedra, revestidas a barro, com lareiras interiores e exteriores. O uso da pedra ter-se-á intensificado com a Idade do Ferro, assim como a presença de muralhas, algumas em talude. No morro central do sítio vêem-se algumas pedras empilhadas que poderão corresponder a tal. Conhecem-se também áreas funcionais definidas dentro dos povoados, onde se praticavam diversas actividades necessárias à subsistência das comunidades, nomeadamente a armazenagem, moagem, tecelagem, metalurgia, olaria, entre outras. Viviam essencialmente da exploração agrícola de cereais e hortícolas, da pastorícia, da caça e da recolecção de frutos de Inverno, nomeadamente da bolota. Existem evidências de produção local, de cariz doméstico, de bronze em praticamente todos os sítios do Bronze Final da Beira Alta, testemunhadas por moldes, escórias, pingos de fundição e alguns fornos. Não temos ainda no CSN qualquer prova de produção metalúrgica embora a ponta de lança de alvado (Senna-Martinez $\&$ alii, 2004) possa ser um indicativo de tal. Este artefacto tem regionalmente paralelo no Castro de S. Romão (Seia), onde além de uma ponta de lança também foi achado o seu molde em cerâmica (Senna-Martinez, 20oob, pp. 140-141). Defende-se que neste mundo do Grupo Baiões/Santa Luzia as peças metálicas seriam símbolos de poder, podendo este artefacto ser testemunho da complexificação da comunidade de CSN. Já a presença de escórias de ferro poderá testemunhar a prática da metalurgia do ferro no sítio durante a Idade do Ferro.

Há ainda a referir que a grande maioria destes fragmentos foi recolhida na vertente Nordeste, podendo eventualmente indicar uma presença mais concentrada ou melhor preservada das comunidades destas cronologias naquela área.

\section{A OCUPAÇÃO MEDIEVAL}

São apenas 10 os fragmentos cerâmicos a torno, maioritariamente rápido, que nos testemunham uma ocupação medieval do sítio. Os fragmentos identificam-se pela sua pasta compacta e xistosa, na maioria de desengordurantes frequentes de pequeno e médio calibre, especialmente micas, e de acabamentos alisados. A cozedura é na maioria redutora, de tonalidades cinzentas, mas também se verificam algumas peças de cozedura mista e ainda um pequeno exemplar de oxidante. A bibliografia parece mostrar-nos uma divisão entre povoados da região com preferência por cozeduras redutoras e outros por oxidantes (Tente, Lantes \& Prieto, 2014, p. 122). Em todos os sítios, no entanto, se verifica que a olaria é maioritariamente de acabamentos alisados, pasta compacta, de desengordurantes frequentes de calibre médio e grande e de origem local (Tente, Lantes \& Prieto, 2014). Em termos morfológicos verifica-se em todos os sítios uma maioria de potes e panelas, seguida dos alguidares e jarros (Tente, Lantes \& Prieto, 2014). Predominam os bordos exvertidos de lábio redondo ou direito, os colos estrangulados e as bases planas angulosas (Tente, Lantes \& Prieto, 2014). No nosso conjunto não existem bases simples que possamos identificar seguramente como medievais, no entanto, existe um bordo aparentemente de orientação direita e com $28 \mathrm{~cm}$ de diâmetro (Figura 5, n⿳ำ 71), o que juntando aos ângulos dos vários bojos com cordão impresso (Figura 4), permite-nos perceber que estamos essencialmente perante fragmentos de talhas, jarros e, como prova a base em disco decorada a punção ( $\mathrm{n}^{\circ} 74$ ), principalmente de alguidares. Os nossos cordões são aparentemente repuxados e dividem-se entre impressão por digitação e por punção. Além da incisão, os cordões plásticos com digitações e punções são das decorações mais típicas desta cronologia e são mais frequentes em alguidares, talhas e em alguns jarros (Tente, Lantes \& Prieto, 2014, p. 133). São, no entanto, os alguidares que nos permitem tirar maiores conclusões sobre esta ocupação já que encontramos vários paralelos para o nosso alguidar em S. Gens (Tente \& alii, 2018a), Sé de Viseu (Rodrigues, 2014), Penedo dos Mouros (Tente, Carvalho \& Pereira, 2018) e Soida (Tente, Lantes \& Prieto, 2014). Os alguidares de fabrico mais fino seriam destinados a conter líquidos para lavagens ou para confecção e consumo alimentar enquanto os mais grosseiros seriam provavelmente para amassar pão (Rodrigues, 2014, p. 146). Por outro lado, Tente, Lantes \& Prieto (2014, p. 136) dizem-nos que os alguidares mais finos e escuros, como o nosso exemplar, seriam característicos dos séculos X a XI d.C. enquanto os mais grosseiros seriam mais típicos entre os séculos XII a XIV d.C..

É de notar que estes fragmentos foram recolhidos sem contexto definido (área geral) mas nenhum faz parte do conjunto recolhido na vertente Nordeste. Caso não se trate de uma simples casualidade, talvez esta vertente com ocupação pré e proto-histórica 
não tivesse sido escolhida como palco para actividades medievais. Tal como se verifica noutros sítios com ocupação contemporânea na região, também este se encontra num cabeço de grande altitude mas que não é o ponto local mais alto o que lhe confere a vantagem de ter boa visibilidade e ao mesmo tempo não ser facilmente identificado na paisagem. Como os outros sítios, também este poderia ter ainda uma muralha com uma só entrada, reforçando a sua defesa. A implantação próxima do rio Távora e suas margens férteis também vai ao encontro da estratégia de ocupação das comunidades alto-medievais que praticariam o cultivo e consumo de leguminosas e alguns cereais, assim como se dedicariam à pastorícia, caça e recolecção, nomeadamente da castanha (Tente $\&$ alii, 2018b, p. 291), fruto ainda hoje típico na região. Estas ocupações seriam possivelmente sazonais e de construções maioritariamente em materiais perecíveis. As escórias de ferro são bastante comuns nestas ocupações, assim como fundos de forja e vários artefactos como pregos e lâminas (Tente $\&$ alii, 2018b, p. 279), pelo que as escórias presentes no nosso conjunto serão mais provavelmente de cronologia medieval.

\section{CERÂMICA "INDIFERENCIÁVEL" E OUTRAS POSSÍVEIS OCUPAÇÕES}

Neste grupo, de 37 fragmentos cerâmicos, entram todos os restantes exemplares que por má conservação ou por grande longevidade de morfologia e fabrico não podem ser seguramente atribuídos a qualquer destes períodos de ocupação (Figura 5). Apenas uma peça é a torno. Todas, sem embargo, apresentam pastas compactas, de textura xistosa e com desengordurantes regionais, na maioria de pequeno calibre e pouco frequentes. A grande maioria apresenta superfícies interiores e exteriores alisadas, encontrando-se apenas 6 peças de superfícies polidas. Existem também 3 casos de engobe sobre alisamento e registam-se 3 exemplares com cepillo. Estamos, portanto, perante fabricos comuns e acabamentos variados. Deste grupo, 22 fragmentos são bordos, na sua grande maioria exvertidos, mas pequenos demais para poder aferir a sua forma e diâmetro. Outros remetem para formas "de fundo comum" que poderão pertencer a qualquer período. É ainda de referir que dois dos bordos demonstram a aplicação da técnica de colombino. Os diâmetros possíveis de calcular estão entre os 8 e os $27 \mathrm{~cm}$, com espessuras entre os 0,4 e 1,8cm o que mais uma vez lhes confere uma grande variedade de tamanhos e morfologias, mas aparentemente com maior incidência nos pequenos e médios potes de armazenagem. A maioria dos lábios são redondos ou direitos, mas também se verificam alguns biselados e espessados. É, no entanto, de destacar a peça no ${ }^{\circ} 8$, de contexto não especificado, que tem a particularidade de ter um bordo enrolado e que deverá pertencer a uma pequena taça a torno de cozedura oxidante, com faces alisadas e poucos desengordurantes. Não conseguimos encontrar-lhe paralelos, mas a sua pasta leva-nos a considerar tratar-se de um testemunho de visitas ao sítio em período romano tardio, mas não podemos, ainda assim, descartar a possibilidade de se tratar de uma intrusão recente.

Contam-se também 4 bases, todas aparentemente planas e provavelmente de recipientes pequenos, no entanto estão todas muito mal conservadas. Embora ainda raras em cronologias anteriores à Idade do Bronze, este tipo de base é conhecido já desde o Calcolítico e estende-se até ao período medieval. Relativamente a elementos de preensão, as asas são de fita, com várias cronologias possíveis. Os arranques apresentam diferentes técnicas de preensão: $\mathrm{o}$ arranque de asa que se encontra num bordo ( $\mathrm{n}^{\circ}$ 32), possivelmente de um pequeno pote, foi repuxado, enquanto o arranque de asa que encontramos solto ( $\mathrm{n}^{-}$31) demonstra que seria cravado. Aparentemente do mesmo recipiente que este último, surge-nos ainda um bojo com uma "perfuração" de grande diâmetro (nº 30) que poderá corresponder ao local de cravagem da asa, no entanto, muito mal conservado. Resta-nos também um bojo onde se verifica que teria algum tipo de elemento de preensão ali colado e que, entretanto, se descolou. Já quanto aos mamilos, que nos surgem com formas e em locais diferentes ( $n^{\circ} 23$ e 35), são bem conhecidos do Calcolítico e Bronze Final, mas a sua má conservação impede-nos, uma vez mais, a aferição de uma cronologia precisa. Inventariámos ainda uma carena, muito subtil e de pasta e acabamentos pouco depurados, pelo facto de apresentar pequenas incrustações nas duas faces daquilo que suspeitamos que seria tinta à base de ocre. Não nos sendo possível recorrer a análises microscópicas ou laboratoriais adequadas, podemos apenas apurar tratar-se de um pigmento de tom e brilho muito vermelho-acobreado. Neste grupo apenas 4 fragmentos são decorados, todos por incisão pré-cozedura e sempre 
na face externa. Os motivos são variados: temos linhas continuas e paralelas na horizontal ( $\left.\mathrm{n}^{\mathbf{0}} 45\right)$, bandas de linhas paralelas na vertical junto ao bordo ( $\mathrm{n}^{\circ}$ 18), pequenas linhas verticais em escada ascendente e descendente (no 8 ) e um reticulado de linhas paralelas e perpendiculares (no 6 ). Todos estes motivos são demasiados vagos e as peças demasiado fragmentadas para poder atribuir-lhes cronologia, sem que as pastas e acabamentos dêem qualquer pista.

Registam-se também, mais provavelmente para as cronologias pré/proto-históricas, dois pedaços de barro seco, com marcas de ramagens, provenientes de áreas diferentes do sítio, um da subida e outro do topo do monte, que reforçam a categorização do sítio como povoado provido de cabanas construídas com materiais perecíveis e revestidas a barro. Há ainda a referir um fragmento que testemunha ocupações mais recentes: uma carena de faiança azul $\left(n^{-} 57\right)$, provavelmente de produção portuguesa do século XVII d.C., ou seja, já dos inícios da dedicação do espaço a Nossa Senhora das Necessidades.

\section{PEQUENAS CONSIDERAÇÕES SOBRE O CONJUNTO LÍTICO}

Recolheram-se no sítio vários artefactos líticos que, apesar da impossibilidade de realizar uma análise detalhada, merecem a sua exposição. São 14 peças, a grande maioria em quartzo: 4 seixos rolados, 3 percutores, 2 lascas e 1 lamela. A estes juntam-se 2 exemplares em anfibolito, um percutor polido e um movente, e ainda uma lasca em sílex e um movente em granito. Como achados de superfície, pouco ou nada se poderá dizer sobre o seu contexto funcional e cronológico. É natural que a maioria destes artefactos seja em quartzo, visto este mineral ser abundante na região e fácil de talhar. Os seixos rolados provavelmente teriam origem no rio Távora ou outros cursos de água próximos, e as suas dimensões, formas e consequentes funções são variadas, desde os mais pequenos seixos com pouco mais de $2 \mathrm{~cm}$ de diâmetro, passando pelos mais ovalados e achatados que provavelmente serviriam de polidores, até aos mais toscos e de maior tamanho, usados para percutir. O movente em granito é também claro, sendo este mineral a base geológica da região e favorável na prática de moagem. Por outro lado, o movente em anfibolito é difícil de explicar, bem como o percutor: esta rocha é mais rara na região e pouco usada para estes fins. Talvez estes dois artefactos repre- sentem objectos de ostentação dentro destas comunidades. Da mesma forma, também o artefacto em sílex poderá ser visto como um objecto de excepção, já que a matéria-prima além de rara na região é também mais fácil de talhar e mais resistente de que o quartzo. Estes artefactos são comuns nos períodos pré/proto-históricos apontados, alguns até em períodos medievais, sendo assim impraticável atribuí-los a cronologias específicas.

\section{POSSÍVEIS CONCLUSÕES SOBRE O SÍTIO}

Apesar de todas as limitações inerentes a uma primeira análise artefactual a um sítio que nunca foi escavado, este estudo permite colocar o Castro de Nossa Senhora das Necessidades no mapa da arqueologia portuguesa para, pelo menos, três períodos cronológicos na região da Beira Alta, e não apenas como "mais um" castro do Bronze Final. Ficam, então, testemunhadas as ocupações durante o Calcolítico, Bronze Final/Idade do Ferro e período Alto-Medieval, ainda que pouco se possa aferir delas. É clara a necessidade de uma intervenção arqueológica neste sítio em destruição, mas que merece ser valorizado para que se possa conhecer e perceber melhor estas ocupações na forma como se inserem no seu enquadramento geográfico e cultural. A vertente Nordeste, em particular, parece-nos ter uma grande potência estratigráfica com uma grande quantidade de artefactos e, quem sabe, talvez até capaz de ainda conservar estruturas e a estratigrafia dos vários períodos, mas que está em iminente perigo com as constantes obras no local e a erosão natural da vertente. Será também necessário que se desenvolvam mais investigações no território circundante de forma a compreender o sítio e as redes de povoamento e contactos na região durante o período medieval, mas, particularmente, ao longo de toda a pré/proto-história.

\section{AGRADECIMENTOS}

Gostaríamos de agradecer à Câmara Municipal de Sernancelhe pelo seu demonstrado interesse nesta investigação e pela cedência dos materiais para a realização deste estudo. Agradecemos igualmente ao Professor Doutor Senna-Martinez (Uniarq) pela cedência do seu conjunto de materiais e por todo o apoio na análise deste. 


\section{BIBLIOGRAFIA}

ALMEIDA, Sara Oliveira (2005) - A Idade do Ferro no Planalto de Viseu: o caso do Morro da Sé. Dissertação de Mestrado apresentada à Faculdade de Letras da Universidade de Coimbra.

ALMEIDA, Sara Oliveira; NÓBREGA, José Ricardo; VILAÇA, Raquel; SILVA, Ricardo Costeira da (2011) - Cerâmica da II Idade do Ferro de Aeminium - R. Fernandes Tomás 72/74 (Coimbra, Portugal). Conimbriga. Coimbra: Faculdade de Letras da Universidade de Coimbra, Vol. 50, pp. 33-57.

BETTENCOURT, Ana Maria dos Santos (2005) - O que aconteceu às populações do Bronze Final do Noroeste de Portugal, no segundo quartel do I milénio AC, e quando começou, afinal, a Idade do Ferro?. In Actas do Colóquio Internacional: Castro, um lugar para habitar. Cadernos do Museu. Penafiel: Museu Municipal, 11, pp. 25-40.

CANHA, Alexandre (2002)-Canedotes: Povoado do Bronze Final do Alto Paiva. Dissertação de Mestrado apresentada à Faculdade de Letras da Universidade do Porto.

LEAL, Augusto Soares d'Azevedo Barbosa de Pinho (1873) Portugal antigo e moderno. Vol 7, Lisboa : Livraria Editora de Mattos Moreira \& Companhia.

MOREIRA, Ab. Vasco (1929) - Cernancelhe e seu Alfoz Terras da Beira. Porto: Officinas do Commercio do Porto.

NEVES, Sílvia Gonçalves (2013) - O Crasto de Tavarede (Figueira da Foz) no quadro das problemáticas da I Idade do Ferro no Baixo Mondego. Dissertação de Mestrado apresentada à Faculdade de Letras da Universidade de Coimbra.

OSÓRIO, Marcos (2009) - A Idade do Ferro no Alto Côa: os dados e as problemáticas. In Lusitanos y vettones. Los pueblos prerromanos en la actual demarcación Beira Baixa - Alto Alentejo - Cáceres. Museo de Cáceres. pp. 95-115.

PEDRO, Ivone (1995) - O povoamento proto-historico da região de Viseu. Dissertação de Mestrado apresentada à Faculdade de Letras da Universidade do Porto, policopiado.

RIBEIRO, Telma Susana (2017) - Cerâmica e áreas funcionais: O conjunto cerâmico do "Ambiente $\mathrm{AW}_{3}$ exterior" do Cabeço do Crasto de S. Romão (Seia). Dissertação de Mestrado apresentada à Faculdade de Letras da Universidade de Lisboa.

RODRIGUES, Patrícia (2014) - Cerâmicas medievais do Pátio do Museu Grão Vasco (Viseu): elementos para uma sistematização da cerâmica pleno medieval do espaço viseense. In Estudos de cerâmica medieval. O Norte e Centro de Portugal-séculos XI a XII. Lisboa: IEM - Instituto de Estudois Medievais (Colecçâo Estudos).

SENNA-MARTINEZ, João Carlos (1989) - Pré-História Recente da Bacia do Médio e Alto Mondego: algumas contribuições para um modelo sociocultural. Tese de Doutoramento em Pré-História e Arqueologia apresentada à Faculdade de Letras de Lisboa, 3 vols., policopiado.
SENNA-MARTINEZ, João Carlos (20ooa) - O problema dos primeiros ferros peninsulares em contextos do Bronze Final da Orla Atlântica: os dados do "Outeiro dos Castelos de Beijós" (Carregal do Sal). Trabalhos de Arqueologia da EAM. Lisboa: Colibri, Vol. 6, pp. 43-6o

SENNA-MARTINEZ, João Carlos (20oob) - O Cabeço do Crasto de São Romão (Seia). In Por Terras de Viriato: Arqueologia da Região de Viseu. Viseu: Governo Civil do Distrito de Viseu e Museu Nacional de Arqueologia, pp. 136-144.

SENNA-MARTINEZ, João Carlos.; ARAÚJO, Maria de Fátima; VALÉRIO, Pedro; PEIXOTO, Horácio (2004) - Estudos sobre a Arqueometalurgia do Grupo Baiões/Santa Luzia: (1) Uma Ponta de Lança do Castro da Senhora das Necessidades (Sernancelhe). O Arqueólogo Português. Lisboa. Série IV, 22, pp. 319-331.

SENNA-MARTINEZ, João Carlos (2013a) - Aspectos do Centro-Norte do Ocidente Peninsular no Final da Idade do Bronze: Povoamento, Metalurgia e Sociedade. Estudos Arqueológicos de Oeiras. Oeiras: Câmara Municipal, 20, pp. 173-19o.

SILVA, Ricardo Costeira (2008) - A passagem da Idade do Bronze para a Idade do Ferro na Beira Interior Centro - estado actual da investigação e enquadramento geral de problemáticas. In Actas das I Jornadas do Património (Belmonte - 21 e 22 de Abril de 2006). Câmara Municipal de Belmonte, pp. 67-82.

TENTE, Catarina; LANTES, Óscar; PRIETO, Pilar (2014) A produção cerâmica dos séculos IX a XI na região do Alto Mondego (Portugal). In Estudos de cerâmica medieval. O Norte e Centro de Portugal - séculos XI a XII. Lisboa: IEM Instituto de Estudos Medievais (Colecção Estudos).

TENTE, Catarina; CARVALHO, António Faustino; PEREIRA, Vera (2018) - O povoado do Penedo dos Mouros (Arcozelo, Gouveia) no contexto do século X no sector noroeste da Serra da Estrela. In Actas do congresso "Do Império ao Reino. Viseu e o território entre os séculos IV a XII”. Viseu. pp. 197-228.

TENTE, Catarina; BAPTISTA, Hugo; TERESO, João Pedro; CÉRCIO, Margarida; VELOSO, João Luís; OLIVEIRA, Cláudia; SEABRA, Luís; MEIRA, Catarina; SOUZA, Gabriel de; CORDERO RUIZ, Tomás; REAL, Manuel Luís (2018b) -Senhora do Barrocal (Sátão) na viragem do milénio. Primeira abordagem. In Actas do congresso "Do Império ao Reino. Viseu e o território entre os séculos IV a XII”. Viseu. pp. 197-228.

TENTE, Catarina; PRATA, Sara; CUESTA-GÓMEZ, Fabián; BROOKES, Stuart; MORENO-GARCÍA, Marta, SOUZA, Gabriel; TERESO, João Pedro; OLIVEIRA, Cláudia; JESUS, Ana (2018a) - Povoamento e modos de vida no limite oriental do território viseense durante o século $\mathrm{X}$ : O Povoado de S. Gens. In Actas do congresso "Do Império ao Reino. Viseu e o território entre os séculos IV a XII". Viseu. pp. 197-228. 
VALERA, António Carlos (1993) - A ocupação calcolítica da "sala 20" do Buraco da Moura de S. Romão. Trabalhos de Arqueologia da EAM. Lisboa: Colibri. Vol. 1, pp. 37-53.

VALERA, António Carlos (2007) - Dinâmicas locais de identidade: estruturação de um espaço de tradição no $3^{\circ}$ milénio AC (Fornos de Algodres, Guarda). Braga: Município de Fornos de Algodres / Terras de Algodres.
VAZ, João Luís Inês (200o) - O Castro de Santa Luzia (Viseu). In Por Terras de Viriato: Arqueologia da Região de Viseu. Viseu: Governo Civil do Distrito de Viseu e Museu Nacional de Arqueologia, pp. 135-136.

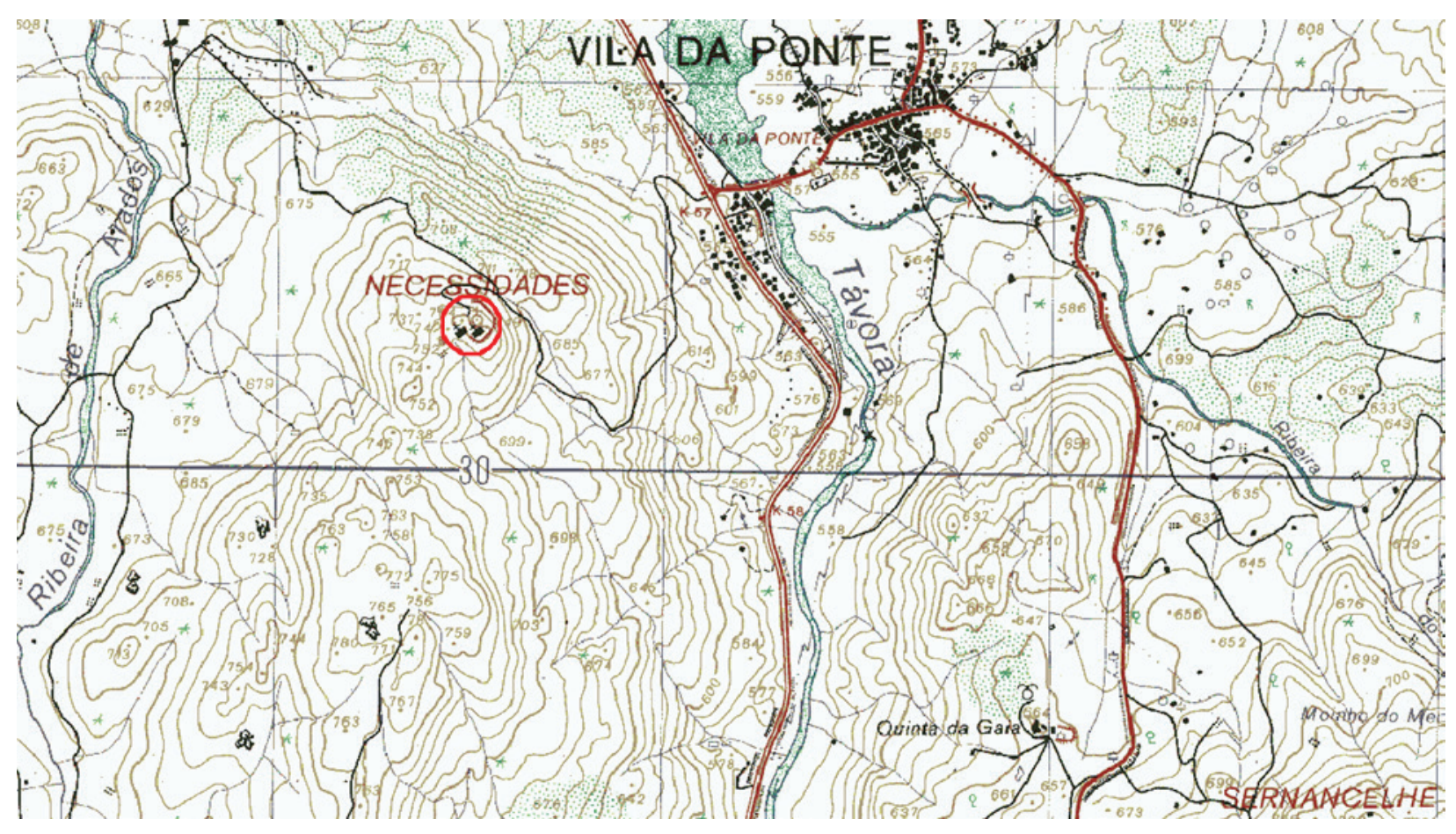

Figura 1 - Localização de CSN na Carta Militar Portuguesa, folha 159 (escala 1:250oo).

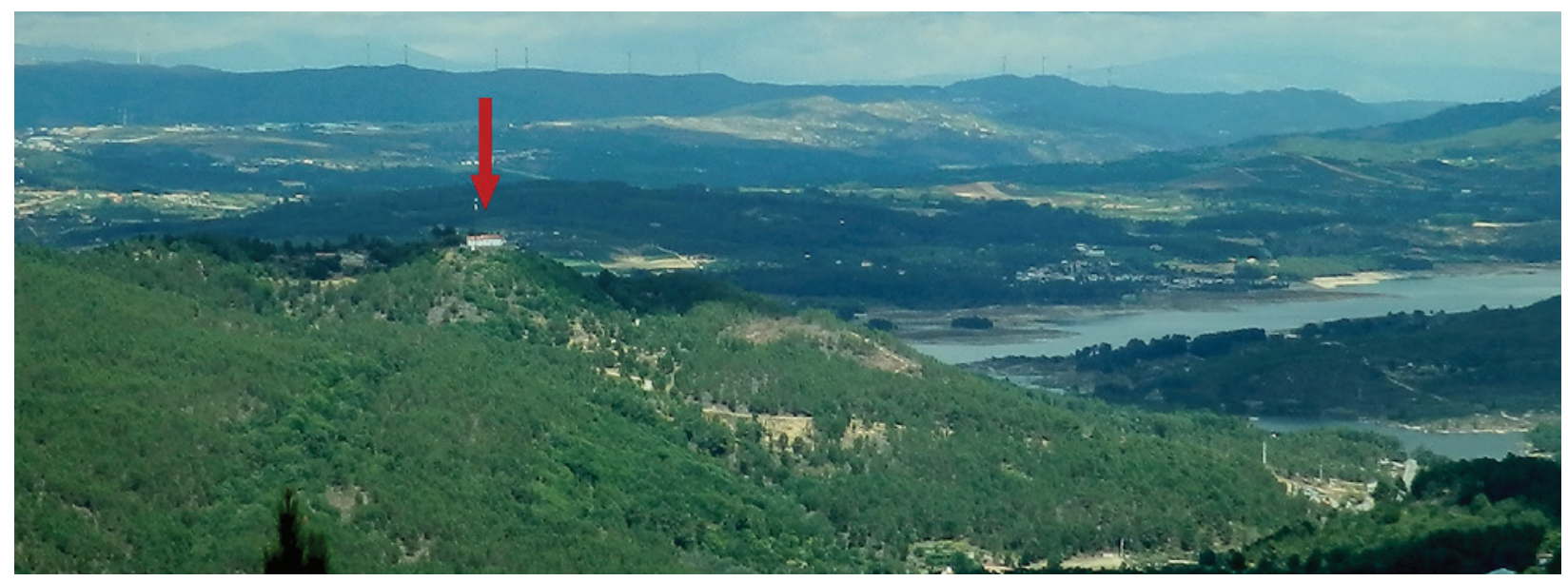

Figura 2 - Localização de CSN na paisagem, visto desde Sernancelhe. 


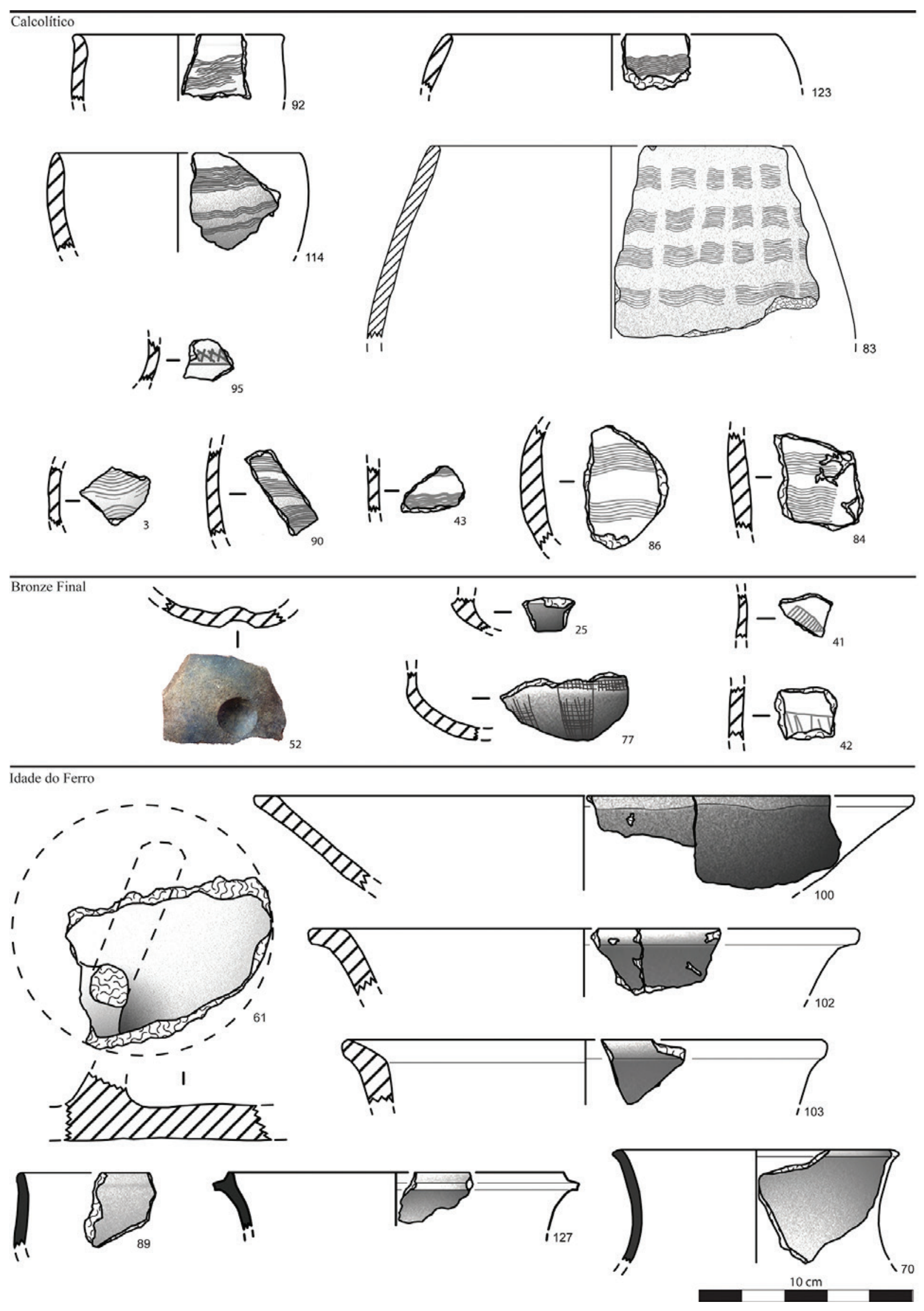

Figura 3 - Cerâmicas do Calcolítico, Bronze Final e Idade do Ferro. 

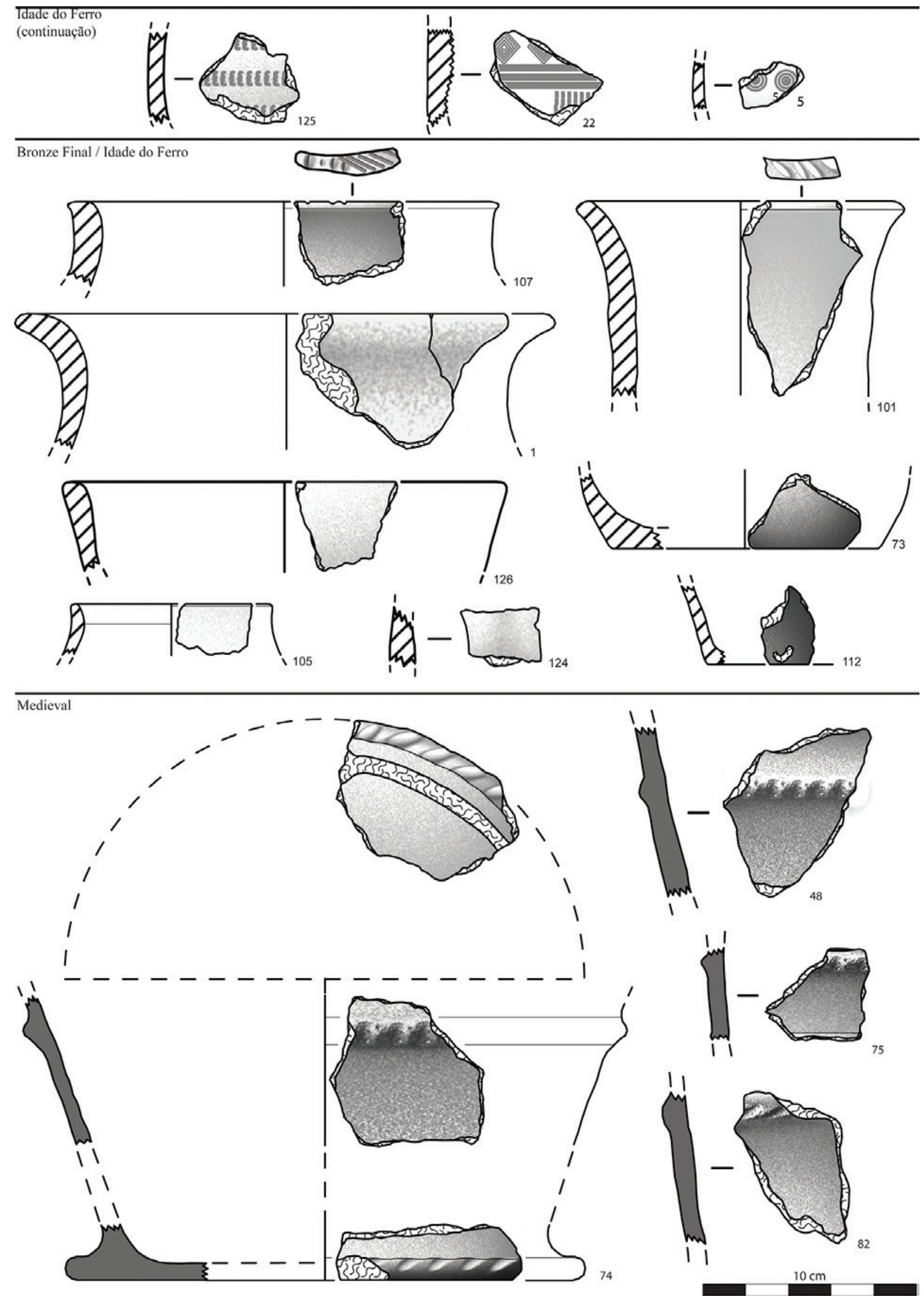

Figura 4 - Cerâmicas da Idade do Ferro (continuação), Bronze Final / Idade do Ferro e Medievais. 


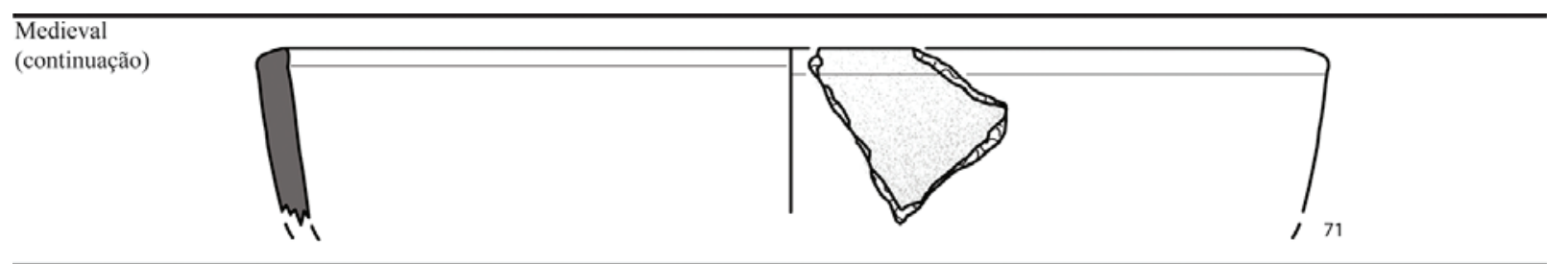

"Indiferenciáveis"
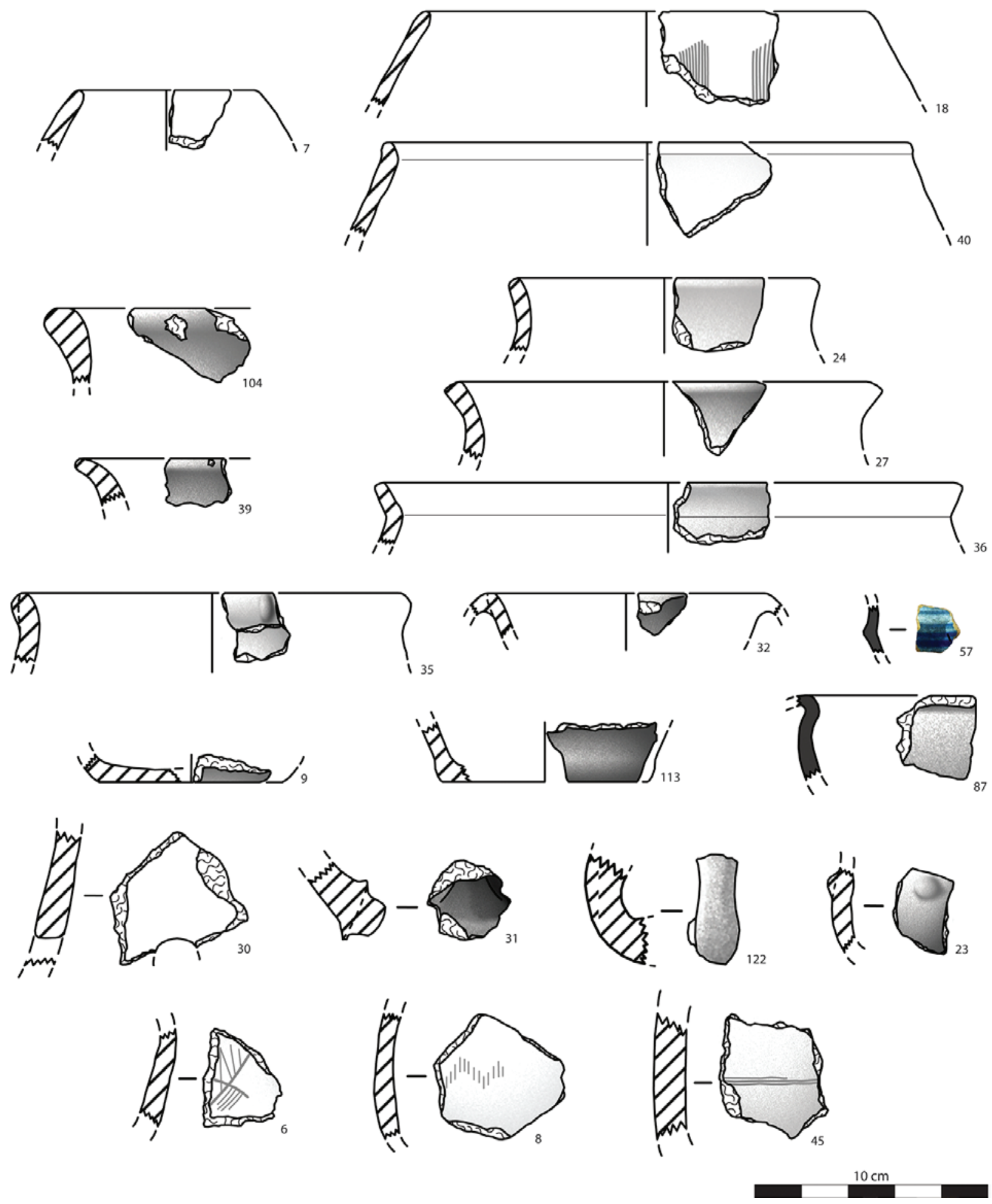

Figura 5-Cerâmicas medievais (continuação) e "indiferenciáveis". 


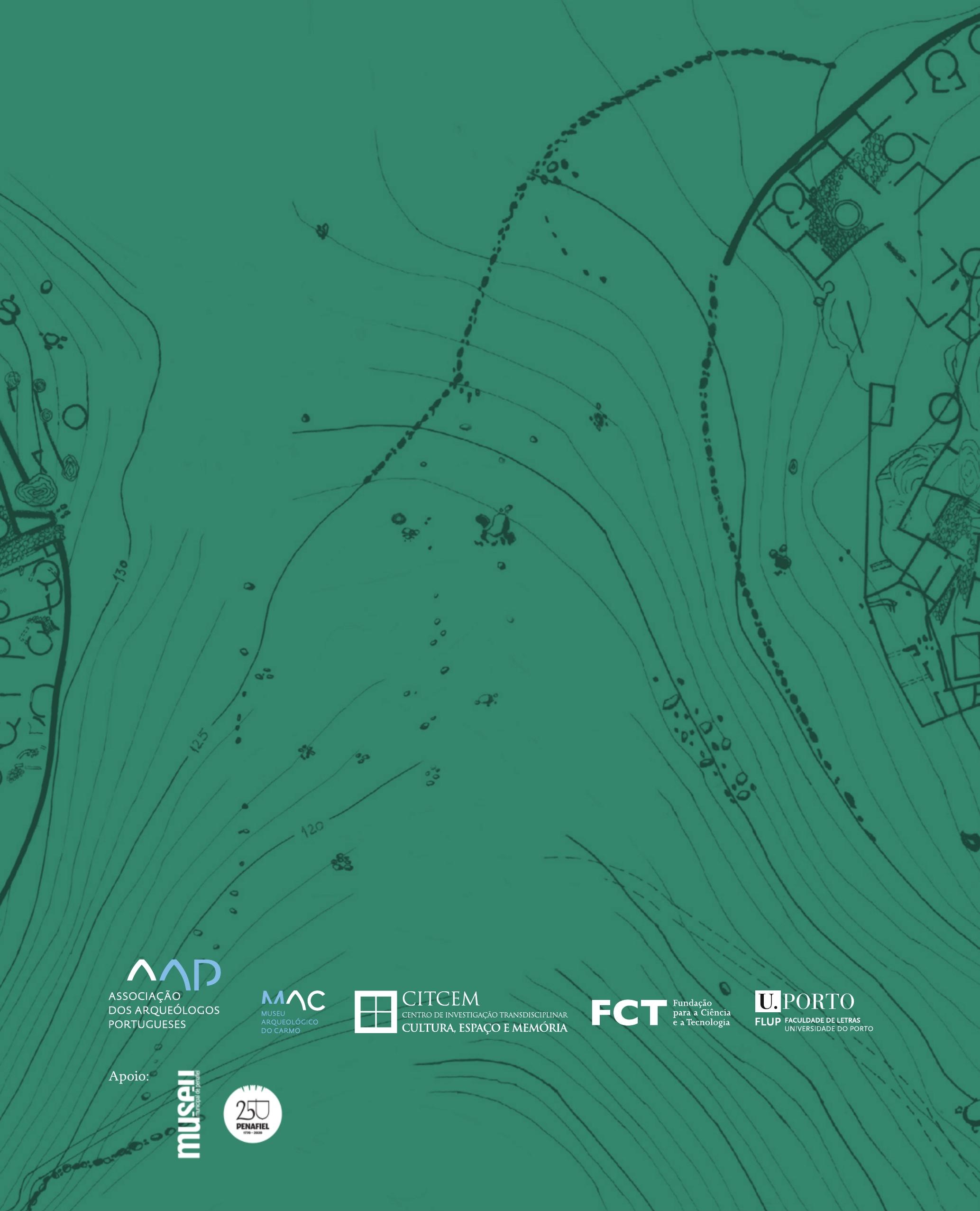

